\title{
EVALUATION AND RISK FACTORS OF ROADHEADERS IN COAL MINES
}

\author{
Erika ŠKVAREKOVÁ, Marianna TOMAŠKOVÁ, Dušan SABADKA, Marian ŠOFRANKO \\ Technical University of Kosice \\ Štefan ZELENÁK \\ Hornonitrianske Bane Prievidza, a.s.
}

\begin{abstract}
:
During mechanical disintegration of the rock, for mining works are used also roadheaders. Roadheaders, in comparison with disintegration by blasting operations can without interuption, and works changes with one machine, dissolve, load and at the same time mine disintegrated rock. These electro-hydraulic machines cause no harmful vibrations and are ideal for mining coal and other soft rock minerals. Mechanical mining is safer, protects the rock environment, allows mining without further breaks, allows you to achieve a higher level of daily progress and also saves work. The analysis of occupational accidents in the Slovak Republic shows that it is necessary require from employees increased attention in any work activity and attention in the work performed (mainly work in handling material, objects and burdens). In the underground coal mines further attention needs to be paid to securing hazardous areas, it is necessary to proceed in such a way as to prevent as much as possible the fall of rock as much as possible Underground roads require modification and equipment in accordance with regulations. It is necessary to follow health and safety instructions mentioned in operating and maintenance documentation. Correction of some deficiencies is ordered by a decision of the Mining Office. Most measures are aimed at adhering to technological discipline, to complement operating documentation, to prevent rock falls, to equip some machinery and transport equipment, to work procedures for handling loads, to maintenance of mining works and for explosion and anti-vapor prevention. In this article, we assess the safety risks of two roadheaders for coal mining works in Slovak conditions. Pairwise comparisons of the criteria of selected roadheaders were used to determine the safety risks, as well as taking into account the risks and safety measures according to the mixed methods following to the standard.
\end{abstract}

Key words: roadheader for coal mining, risk, safety

\section{INTRODUCTION}

Safety and protection of the health while working is the state of the working conditions eliminating dangerous and harmful factors of the working process, or the environment on the employees. All the components of the work process have to be beneficial and safe towards health, working conditions, machines, technical equipment and working methods, organization of the work and the relationship between them. According to law 6 of the Act $124 / 2006$ [1], the statute about the protection of the health and safety of the workers, the employer is obligated to verify dangers, threats, judge risks and evolve written document about risk assessment for all the activities executed by the employees.

Risk analysis is generally rated by three main steps, answers. The first is the risk and threats have connected into the system they are identified together with potentially dangerous events.

The second step usually includes deductive analysis and identification of the cause in every risk event and assessment of the risk situation frequency, based on the experience and expert valuation. Final inductive analysis has used here to identify all the potential sequences of events, which can occur at the risk occasions. Dissection can be quantitative or qualitative, depends on the main aim of its consideration. A mining roadheader is a machine used for mechanical mining of coal seams. It performs several work operations simultaneously (eg. uncoupling, loading and removal of rock to the following transport equipment), which ensures continuous excavation of mining parts, or mining, high performance and work safety. 
Measures are constantly needed to further raise awareness of employees safety. It is necessary to pay attention to the quality and level of educational activities, periodic trainings, professional courses and training of all employees. It is crucial to carry out continuous inspections of compliance with operational documentation and basic principles of safety in the underground.

\section{LITERATURE REVIEW}

Quantitative analysis provides the numerical setting of the results connected to uncertainty. It is the most suitable for quantifying hazard which is related to low probability and high illative case [2].

Analysis means date change focused on the risk of deciding substantial information. Professionals are claiming that (FIR - Fourth Industrial Revolution) is coming shortly and it will change how people work, eat and consume and also the way they think [3].

The first industrial revolution led to changes in the labour market, replaced the manual work with the invention of the steam engine, and the second Industrial Revolution allowed mass production with the electricity [4]. The Tertiary Industrial Revolution began automation and continued computerisation based on computers and the Internet [5]. The FIR will be based on robotization, computer physical system and artificial intelligence and will significantly change human intellectual work in the future. In the future, operational technologies or computer physical system devices will monitor, coordinate and integrate real-time information [6]. If human work is replaced by machines, the labour market will be significantly affected [7]. The development of technology increases labour productivity and creates new jobs. At national and sector level, FIR may have little influence but will reduce employment in local economies and sectors [8, 9]. According to the survey, the largest number of robots in the last period was introduced in the automotive industry, in the electronic industry and the raw materials industry [10]. Currently, process control models are also being addressed in coal mines. Methods of analysis and synthesis are used to set standards in mining companies, as mentioned in the literature $[11,12]$.

Application of a system supporting the management of mining machines/equipment will also enable a better, more effective use of employees. As a result of these actions, the time needed for preparations and repair will be shortened, which will translate directly into the economic effects of mines [13, 14].

The article rates the safety risks of the two mining roadheaders, which are currently most commonly used in Slovak conditions, but also in the Czech Republic, Poland and Germany in the coal mining $[15,27,28]$. For the mechanized minting of horizontal mining works, both the GPK4 and AM50 roadheaders are currently used in Slovak conditions. These mining roadheaders are further subjected to detailed examination from the point of view of safety risks. The evaluation is done using the FDMM-modified method of the decision matrix (Forced Decision). The scales of individual criteria (K1-Material handling, K2-vibration, K3-machine performance, K4-operator safety), as well as the assessment of variants (D1-GPK4, D2-AM50) as they meet individual criteria, are determined by the socalled Matching.

\section{DESCRIPTION OF SELECTED ROADHEADERS}

Two types of roadheaders are used in the article GPK4 and AM50.

\section{Technical description of Roadheaders GPK4}

The usage of roadheader GPK4 in mines secured and safe in terms of the presence of gas and dust is accepted subject to compliance with the requirements of safety regulations, Fig. 1, 2.

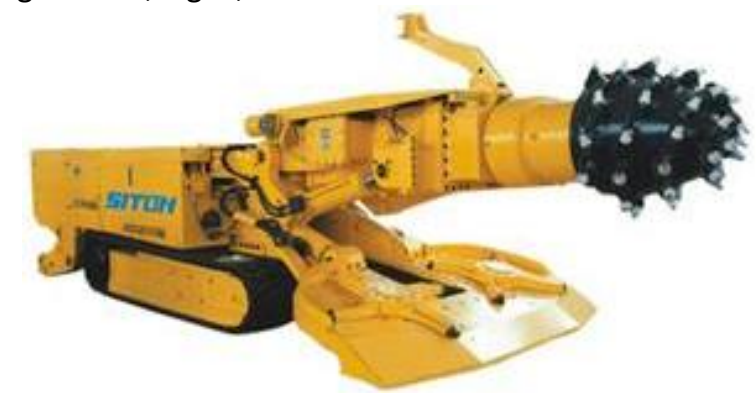

Fig. 1 Roadheader GPK4

Source: [17].

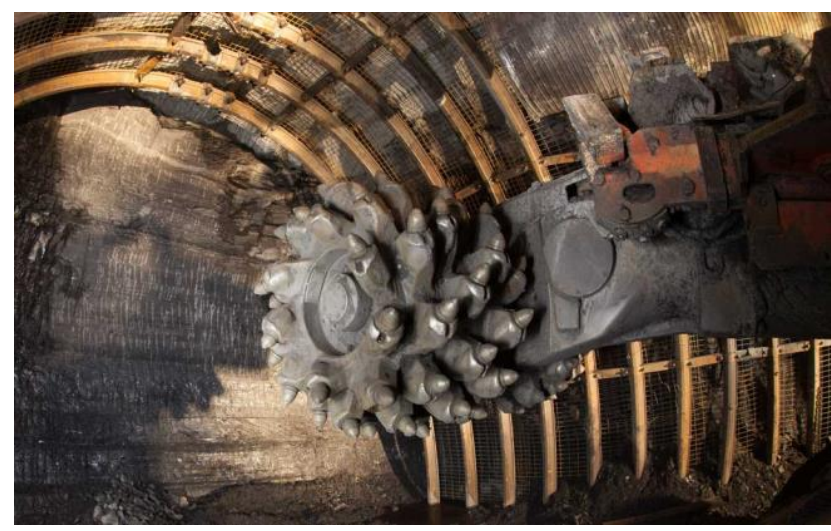

Fig. 2 Working with a roadheader

Source: [17].

The roadheader could be operated after the extension of the arm of the cutting body to the additional attachment PN 35 with hydraulic embedment machine HPO 2000i, the turning gear NZ 2010 and the SPV 01 drilling kit.

The roadheader could have operated in macroclimatic rayon with the mild climate at ambient temperature +5 to $+35^{\circ} \mathrm{C}$.

The electronic equipment of the roadheader has been made in a mining non-explosive version (RV).

When extracting a mining work, the roadheader has placed in the axis of the mining work. Using a mobile part formed by self-propelled caterpillars carts, to which the basic parts are mounted, the roadheader has moved to the heading face. The cutting head is installed on the boom shaft. It is using the hydraulic cylinders of the telescopic ejection to cut in a heading face at a depth of 350-500 mm. 
The disconnecting body located in the swivel tower, is with a help of hydraulic rollers moving horizontaly and verticaly on the surface and it is disintegrating the heading face.

The disjoined rock is picked up by a gathering- arm loader to scraper conveyor with a rear swivel part.

This swivel part allows to load the rock on a scraper or belt conveyor, located at the foot-wall of the mining work [16]. The Roadheader GPK4 consists of the following primary components:

- Disconnecting body,

- Loader,

- Mobile part,

- Conveyor,

- Hydraulic system,

- Command,

- Electronic equipment,

- Dust Disposal Equipment,

- Hydraulic feeder HPO 2000i,

- Rotating eguipment NZ 2010.

Safety measures and prohibited activities during work with roadheader GPK4

Prohibited activities while working with the machine:

- reversing operation of the conveyor during the swing section of the rotating conveyor,

- carry out repairs on the electrical equipment of the roadheader to all crew members except electrician,

- change of the control scheme.

It shall be strictly prohibited:

- use of unfiltered oil,

- oil containing a small amount of moisture.

Precautions:

- all work with the GPK, HPO2000i and VPS-01 roadheader must be carried out under the applicable standards with the regulations established by the management of the organization eg. mining legislation, technological procedures, normative fire safety.

Prohibited activities:

- during the operation of the conveyor to modify pieces of rock, strain the scraper conveyor and perform the cleaning,

- work on conveyor drive with the removed shield of the telescopic shaft,

- walking under the conveyor and the presence of workers in the discharge points,

- low-light operation,

- operation at poor service,

- service in the case of dismantled shield on the conveyor,

- do not allow an uncertified serviceman to operate a roadheader GPK4,

- operation of the roadheader when technical dust disposal equipment is not in service;

- any repairs and inspections of electrical parts, hydraulic or mechanical parts at the time of operation,

- carrying out work on the hydraulic system/tightening of joints, or replacing hoses/at the raised conveyor, loader and disconnection body. Before starting these works, the conveyor, loader and disconnection body must run on reliable support,

- replacement of hoses of hydraulic cylinders tensioning the scraper chain without reliable assistance under the conveyor to prevent the conveyor from falling spontaneously. It should have to be remembered that the chain tensioning system is connected to hydraulic cylinders lifting the conveyor and the induced leakage in the chain tensioning system causes the conveyor to drop.

Operator qualification:

- the operator of the machine has to be demonstrably acquainted with the technical conditions,

- furthermore, he has to qualify a person instructed under STN 34 3100,

- he has to comply with the SBÚ (Slovak Mine Office) Decree no. 21/1981 Coll., Regulation for roadheader operation and operating regulations approved by the company's management for roadheader.

Controls don before turning on the machine:

- perform a proper check of the tow cable status,

- its fixing, checking the clamping of the tow cable control the tow cable, its hanging,

- visual inspection is necessary, tightening of the locking screws and inviolability of non-explosive cabinets,

- test the action of machine, check the correct direction of electric motors rotation, all propulsions, especially for hydraulic units and correct the errors.

Inspection during operation of the machine:

- observe the operating mode so that the electric motors are not overloaded its surface temperature can not exceed $80^{\circ} \mathrm{C}$,

- remove coal grit and other impurities from the bodies of the electric engines,

- ensure cables against mechanical damage, rockfall while driving and manoeuvring, be careful not to move the cord or excessively pull the cord,

- systematically and regularly check the reliability of the fastening of all cable lines and outlets, fastening the covers on the motors and the electric cabinet,

- proper handling of the machine limits the frequent switching of individual appliances on the unit.

- Maintenance of electrical equipment of the roadheader GPK4.

Every shift:

- perform a regular check of the general condition of all cables, tightening the power cord, hanging the rope, its attachment to the machine and individual quick couplers,

- check the terms of the motor coverage, the electrical cabinets, purity of the entire power equipment and the temperature of all-electric motors, these works are carried out by the operation according to a decree of the SBÚ (Slovak Mining Office) No 21/1981 Z.,

- checking the completeness and integrity of non-explosive caps, functional operational control of the control buttons, blocking and controlling the remote control 
of the supply contactor, these works are performed by an operating electrician each shift.

Weekly inspections:

As with daily controls, besides, we have to do:

- measurement of the insulation status of the roadheader by the measuring instrument (magnet),

- measurement of the integrity of the ground conductor, control of the controls, tightening of all joints and screws.,

- sorting of contacts, lubrication of individual mechanisms, checking conservation and the preservation of non-explosive top wad, state of electric circuit and cleaning of the test chambers,

- control the main contactor,

- an operating electrician carried out all these works.

Monthly controls: as with weekly, besides:

- inspection of hinges on cables and measurement of insulation states. Tighten the screws under all-electric motors and screws fixing the electric cabinet [17].

\section{Technical description of Roadheader AM50}

The roadheader AM50 has been produced by the Austrian company VOEST-ALPINE Bergtechnik, the beginning of production dates back to the 1970s, Fig. 3, 4.

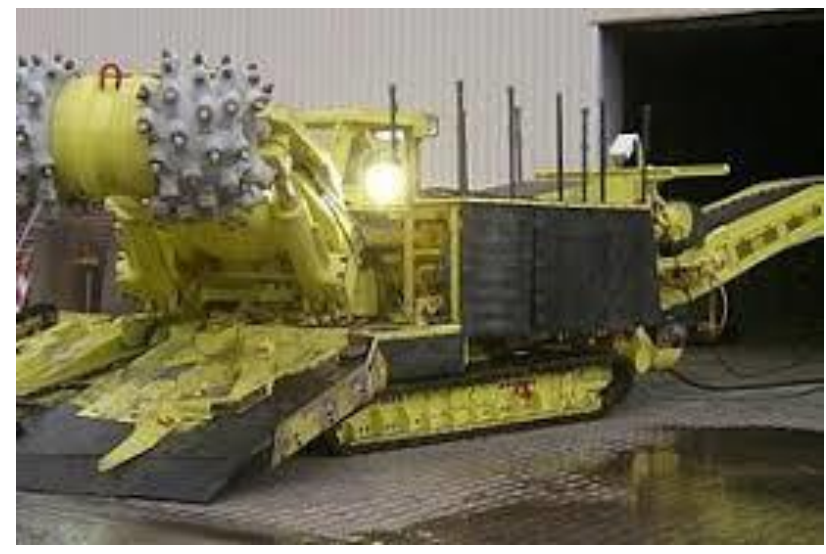

Fig. 3 Roadheader AM50

Source: [18].

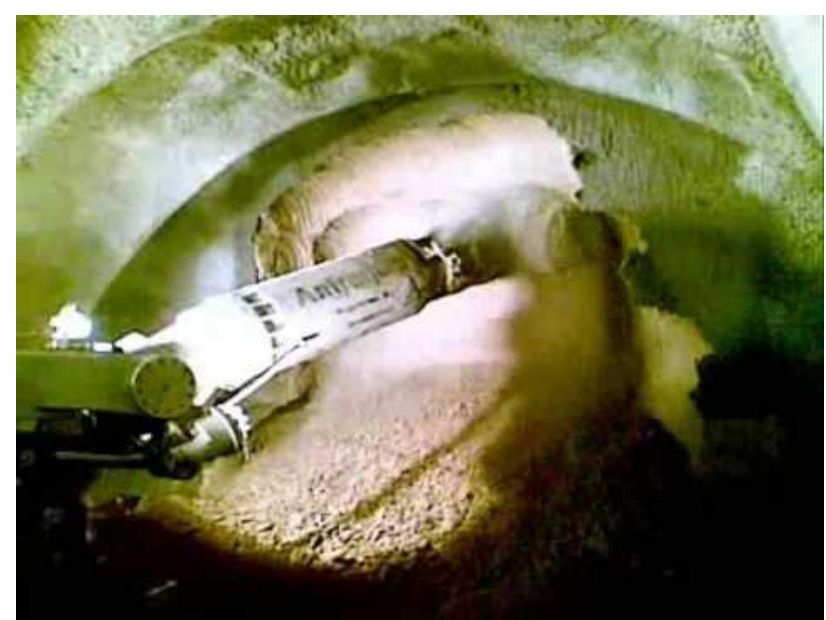

Fig. 4 Roadheader AM50 in mining operation

Source: [18].
This roadheader is designed for rock extraction with strength up to $80 \mathrm{MPa}$ with the possibility of gaining smaller layers with greater strenght. Extraction is possible in a loss or sprain up to 16 degrees. The profile of the corridor from one position of the roadheader has an area of $12.5-17 \mathrm{~m}^{2}$, the shape of the mining hall can be trapezoidal, rectangular or arc. The maximum width of the drilling work is about 4.6 the height is $3.6 \mathrm{~m}$. However, the relocation of the machine can also allow extraction works of larger sizes.

The boom with disconnecting head consists of a watercooled electric motor, a gearbox and a disconnecting body. The gearbox allows you to switch between two to three speeds. The disconnecting body is composed of two cutting heads which have an axis of rotation perpendicular to the axis of the boom fitted with tangential blades of carbide alloy.

The blades can rotate in the holders during disconected, ensuring their even abrasion. Of course, there is also a folding device of the disconecting organ. The swivel device secures the movement of boom with usage of hydraulic cylinders and hydraulic turning device. The loading device ensures the transfer of the rock to the scraper conveyor using adjustable blades and loading shoulder. The width of the blade is $2 \mathrm{~m}$ and can be extended to $2.5 \mathrm{~m}$ or $3 \mathrm{~m}$ using attachments.

At the time of perforation, the blade serves as the front support of the roadheader. The scraper conveyor consists of a chain, frame, drive and reversible station and it is used to move the disjoint rock to the rear of the roadheader. The machine frame is a massive structure that carries all the other parts its support, is so-called "stabilizing foot". The drive wheels of the belt can be disconnected, allowing the machine has been transported by towing. The undercarriage has for every belt individual drive and driving wheels of the belt could be disconnected, allowing transport of the machine by trailing [19].

The hydraulic system is composed of an oil tank with a piston pump, control and control devices and hoses. The electrical equipment includes all electric motors, switching equipment, lighting and cables and has created in a non-explosive environment.

The roadheader AM50 can be equipped with a device which allows enlargement of cutting profile of roadheader. Machine equipment further more includes: lifting device or reinforcement arc and working platforms for building reinforcement.

The roadheader AM50 consists of the following fundamental parts:

- Cutting arm,

- Rotating device,

- Loading device,

- Chain conveyor,

- Belt chassis,

- Frame,

- Electrical equipment,

- Hydraulic equipment. 
Safety measures and prohibited activities during work with roadheader AM50

Prohibited activities while working with the roadheader:

- the use of the security power switch and the emergency switch that rejects all parts of the machine from function and locks them against usage,

- the security power switch is situated at the worker position and also on the opposite side of the machine,

- another warning elements are warning signs that give a signal before the power drives start, this signal has a distinct and unmistakable sound that must last at least 5 s and should not exceed 10s. After this signal has expired, the power drives self-start [18].

Another security measures and prohibited activities which have applied for roadheader AM50 are similar as for the roadheader GPK4, mentioned in the section Security measures and prohibited activities of roadheader GPK4.

\section{Basic technical specifications of two roadheaders GPK4} and AM50

Table 1 summarises the basic technical parameters of the GPK4 and AM50 mining roadheaders their safety risks will be further estimated and compared.

Table 1

Basic technical parameters of two roadheaders GPK4 and AM50

\begin{tabular}{|c|c|c|c|}
\hline $\begin{array}{l}\text { Technical } \\
\text { parameters }\end{array}$ & Units & $\begin{array}{c}\text { Roadheader } \\
\text { GPK4 }\end{array}$ & $\begin{array}{c}\text { Roadheader } \\
\text { AM50 }\end{array}$ \\
\hline height & $\mathrm{mm}$ & 1500 & 1645 \\
\hline chassis width & $\mathrm{mm}$ & 1600 & 1580 \\
\hline lenght & $\mathrm{mm}$ & 10000 & 7500 \\
\hline weight & kg & 18000 & 22200 \\
\hline load on thill & $\mathrm{MPa}$ & & 0.13 \\
\hline $\begin{array}{c}\text { driffting } \\
\text { performance }\end{array}$ & $\mathrm{Mg} / \mathrm{min}$ & 1.8 & $0.43-1.74$ \\
\hline width of loader & $\mathrm{m}$ & $1875-1960$ & $\begin{array}{l}2200-2500- \\
3000\end{array}$ \\
\hline speed of advanced & $\mathrm{m} / \mathrm{min}$ & $2.52-6.8$ & 5 \\
\hline $\begin{array}{c}\text { power performance in- } \\
\text { stalled } \\
\text { Parameters } \\
\text { of mining work }\end{array}$ & kW & 95 & 155 \\
\hline corridor inclination & degree & 10 & 16.8 \\
\hline height & $\mathrm{mm}$ & $1800-3600$ & 4000 \\
\hline width next to foot wall & $\mathrm{mm}$ & $2600-4700$ & 4800 \\
\hline area & $m^{2}$ & $4.7-15$ & 17.2 \\
\hline
\end{tabular}

Table 2 where are compared the basic technical paramenters of both mining roadheaders provide differences between GPK4 roadheader of Russia origin and AM50 of Austrian origin.

Roadheader AM50 of has:

- higher power output during mining work,

- is heavier,

- needs higher instalation power output.
Table 2

Comparison of the roadheaders GPK4 and AM50 according

to the basic parameters

\begin{tabular}{|c|c|c|}
\hline Technical parameters & Units & Comparison AM50 vs. GPK4 \\
\hline height & $\mathrm{mm}$ & higher by 145 \\
\hline chassis width & $\mathrm{mm}$ & shorter by 20 \\
\hline lenght & $\mathrm{mm}$ & shorter by 250 \\
\hline weight & $\mathrm{kg}$ & heavier by 420 \\
\hline driffting performance & $\mathrm{Mg} / \mathrm{min}$ & appropriately the same \\
\hline width of loader & & wider from 350 to 1040 \\
\hline speed of advanced & $\mathrm{m} / \mathrm{min}$ & appropriately the same \\
\hline $\begin{array}{l}\text { installed engine power } \\
\text { total }\end{array}$ & $\mathrm{kW}$ & higher by 60 \\
\hline $\begin{array}{l}\text { Parameters of mining } \\
\text { work }\end{array}$ & & \\
\hline corridor inclination & degree & bigger by 6.8 \\
\hline height & $\mathrm{mm}$ & higher by 400 \\
\hline chassis width & $\mathrm{mm}$ & bigger by 100 \\
\hline area & $m^{2}$ & bigger by 2.2 \\
\hline
\end{tabular}

\section{METHODOLOGY}

Analysis had been done according to following processes, which are used for the valuation of the survey:

1. security evaluation of the roadheaders according to technical and safety regulations,

2. creation of the criteria file according to the present knowledge,

3. identification of the importance criteria file, to choose the optimal variant.

The mentions roadheaders are subjected to detailed examination from the point of view of safety risks. The evaluation is done using (Table 3 ):

1. the FDMM-modified method of the decision matrix (Forced Decision),

2. the scales of individual criteria (K1-material handling, K2-vibration, K3-machine performance, K4-operator safety),

3. the assessment of variants (D1-GPK4, D2-AM50) as they meet individual criteria, are determined by the so-called Matching.

Table 3 Evaluation criteria for the choice of the optimal variant Roadheader: D1-GPK4, Roadheader: D2-AM50

\begin{tabular}{cccc} 
Criteria & \multirow{2}{*}{ Weight } & \multicolumn{2}{c}{ Machine evaluation } \\
\cline { 3 - 4 } & & D1-GPK4 & D2-AM50 \\
\hline K1-manipulation with material & 7 & 8 & 7 \\
K2-vibration & 6 & 6 & 8 \\
K3-power efficiency of the ma- & 8 & 7 & 6 \\
$\begin{array}{c}\text { chine } \\
\text { K4-safety maintenance }\end{array}$ & 9 & 8 & 7 \\
Estimated total & & 220 & 208 \\
Order & & 1 & 2 \\
\hline
\end{tabular}

Source: [21, 22].

This means that when comparing two criteria, it is more significant (for decision making more important) criterion rated "1", a less significant criterion of "0". Similarly, when evaluating how two variants meet the chosen evaluation criteria, the variant is better, rated " 1 " and the variant rated worse "0" [16]. 
In the below mentioned table are noted evaluation criteria for the choice of the optimal variant according to the present knowledge [20].

The second assessment is a risk assessment method that quantifies qualitative parameters. It is a mixed method of numerical scoring and matrix.

While the assessment of the optimal variant it is preferable based on evaluation of working group - roadheader GPK4. In the Table 4-8 continues couple comparison of the variants according to individual criteria.

Table 4

Couple comparison of the criteria of the chosen roadheaders K1-manipulation with material, K2-vibrations, K3-performance of the machine, K4-maintenance safety

\begin{tabular}{ccccccc} 
Criteria & K1 & K2 & K3 & K4 & Total & Weight \\
\hline K1 & - & 0 & 1 & 1 & 2 & $2 / 3=0.666$ \\
K2 & 0 & - & 0 & 1 & 1 & $1 / 3=0.333$ \\
K3 & 1 & 0 & - & 1 & 2 & $2 / 3=0.666$ \\
K4 & 1 & 1 & 1 & - & 3 & $3 / 3=1$ \\
\hline
\end{tabular}

Source: $[23,24]$.

A more significant criterion is rated number 1 and the less relevant standard is number 0 . While the comparison of both of criterion, it is more relevant and for decision-making criterion evaluated number 1 , and less relevant criterion number 0 . Similar while evaluation of that, then two variants compliant of the chosen evaluation criterion, the variant more suitable is evaluated number 1 and variant evaluated worse number 0 .

In Table 4 the definite criterion with the higher importance is the maintenance safety criterion.

Table 5 according to pair comparison of the criterion $\mathrm{K} 1$ and Table 5 was preferred criterion is manipulation with material of roadheader GPK4.

Table 5

Pair comparison of the versions according to criterion $K 1$

\begin{tabular}{ccccc} 
Version & D1-GPK4 & D2-AM50 & Total & Valuation \\
\hline D1-GPK4 & - & 0.5 & 0.5 & $0.5 / 2=0.25$ \\
D2-AM50 & 0 & - & 0 & $0 / 2=0$ \\
\hline
\end{tabular}

Table 6

Pair comparison of the versions according to criterion $K 2$

\begin{tabular}{ccccc}
\hline Version & D1-GPK4 & D2-AM50 & Sum & Valuation \\
\hline D1-GPK4 & - & 1 & 1 & $0.5 / 2=0.25$ \\
D2-AM50 & 0.5 & - & 0.5 & $0 / 2=0$ \\
\hline
\end{tabular}

For the criterion of the vibration is more suitable roadheader GPK4.

Table 7

Pair comparison of the versions according to criteria K3

\begin{tabular}{ccccc} 
Version & D1-GPK4 & D2-AM50 & Sum & Valuation \\
\hline D1-GPK4 & - & 0.5 & 0.5 & $0.5 / 2=0.25$ \\
D2-AM50 & 0 & - & 0 & $0 / 2=0$ \\
\hline
\end{tabular}

For the criterion of the machine efficiency, it is more favourable roadheader GPK4.
Table 8

Pair comparison of the versions according to criterion $\mathrm{K4}$, according

\begin{tabular}{ccccc}
\hline Version & D1-GPK4 & $\begin{array}{c}\text { D2- } \\
\text { AM50 }\end{array}$ & Sum & $\begin{array}{c}\text { Valua- } \\
\text { tion }\end{array}$ \\
\hline D1-GPK4 & - & 0 & 0 & $0 / 2=0$ \\
D2-AM50 & 1 & - & 1 & $1 / 2=0.5$ \\
\hline
\end{tabular}

For the criterion of the safety, maintenance is more favourable roadheader AM50.

According to risk ranking, it is clear, that it is necessary to propose protective measures $1,4,5,6,7$, so that it would be very improbable to come across with working injuries and the manipulation with a particular machine will be secure.

Table 9

Decision making according to Table 3

\begin{tabular}{cccc}
\hline Criterion & Weight & \multicolumn{2}{c}{$\begin{array}{c}\text { Valuation of the } \\
\text { roadheaders }\end{array}$} \\
& & D1-GPK4 & D2-AM50 \\
\hline Manipulation with material & 0.666 & 0.25 & 0 \\
Vibration & 0.333 & 0.5 & 0.25 \\
Performance & 0.666 & 0.25 & 0 \\
Maintenance safety & 1 & 0 & 0.5 \\
Weighted Total Sum & & 1 & 0.75 \\
Order & & 1 & 2 \\
\hline
\end{tabular}

The final evaluation of the versions or the weight criterion can be reached in such a way, that the ranking is "normed“, that means we request, that the total of the all evaluations - weights will be equal 1 , Table 9 . The risk assessment method in Table 10. Due to different hazardous situations and events, the same hazard can be expected, where:

Se - The severity of the possible damage as a result of the identified threat is defined.

$\mathrm{Fr}-$ is the average interval between the frequency of exposure and its duration.

$\mathrm{Pr}-$ is the probability of a dangerous event occurring. The probability level is taken into account for example, human behavior, parts reliability, accident statistics, and part or system characteristics.

$A v-$ is the possibility of preventing or limiting damage.

For example, it is taken into account when determining the level of prevention consider whether the machine will be operated by qualified or unqualified persons before it can cause damage to the situation.

$\mathrm{Cl}$ is a category, $\mathrm{Fr}, \mathrm{Pr}$ and $\mathrm{Av}$ are the factors that make up the probability of damage. The risk is assessed using a matrix. There are severity intersects category $\mathrm{Cl}$ in the black area, risk mitigation measures have to be implemented. When severity Se intersects class $\mathrm{Cl}$ in the gray area, it is recommended to introduce protective measures to further reduce the risk.

When the severity intersects class $\mathrm{Cl}$ in the rest of the area, the risk is already sufficiently reduced. Indicate the protective measure to be taken to reduce the risk. 
Risk evaluation of the mining combine GPK4 according to standard TNI ISO/TR 14121-2

\begin{tabular}{|c|c|c|c|c|c|c|c|}
\hline \multirow{2}{*}{$\begin{array}{c}\text { Combine GPK-4 } \\
\text { Consequences } \\
\end{array}$} & \multicolumn{7}{|c|}{ Risk evaluation and safety measures according to the mixture method [26] } \\
\hline & Severity "Se" & \multicolumn{2}{|c|}{ Frequency "Fr" } & \multicolumn{2}{|c|}{ Probability "Pr" } & \multicolumn{2}{|c|}{ Prevention "Av" } \\
\hline $\begin{array}{l}\text { of an eye or } \\
\text { of an arm }\end{array}$ & 4 & $\begin{array}{l}\text { less than one } \\
1 \text { hour }\end{array}$ & 5 & Very high & 5 & & \\
\hline $\begin{array}{l}\text { Permanent injury, } \\
\text { loss of the fingers }\end{array}$ & 3 & $\begin{array}{l}\text { more than } \\
1 \text { hour until } \\
24 \text { hours }\end{array}$ & 5 & Presumably & 4 & & \\
\hline $\begin{array}{l}\text { Reversible injury, } \\
\text { medical attention }\end{array}$ & 2 & $\begin{array}{l}\text { More than } \\
24 \text { until } 2 \text { weeks }\end{array}$ & 4 & Possible & 3 & Impossible & 5 \\
\hline \multirow[t]{2}{*}{$\begin{array}{l}\text { Reversible injury, } \\
\text { first help }\end{array}$} & 1 & $\begin{array}{l}\text { More than } \\
2 \text { weeks untill } \\
1 \text { year }\end{array}$ & 3 & Rarely & 2 & Possible & 3 \\
\hline & & more than 1 year & 2 & Negligible & 1 & $\begin{array}{l}\text { Probably - } \\
\text { presumably }\end{array}$ & 1 \\
\hline
\end{tabular}

\begin{tabular}{|c|c|c|c|c|c|c|c|}
\hline $\begin{array}{c}\text { Serial } \\
\text { number }\end{array}$ & $\begin{array}{c}\text { Danger } \\
\text { according } \\
\text { to maintenance }\end{array}$ & Se & $\mathbf{F r}$ & Pr & Av & Cl & Protective measures \\
\hline 1) & $\begin{array}{l}\text { Danger during } \\
\text { service }\end{array}$ & 3 & 4 & 4 & 3 & 14 & \multirow{7}{*}{$\begin{array}{l}\text { The requirement of the security } \\
\text { measures in the manual for the } \\
\text { operation according to Directive } \\
\text { 2006/42 Machinery Directive }\end{array}$} \\
\hline 2) & $\begin{array}{l}\text { Danger } \\
\text { according } \\
\text { to noise }\end{array}$ & 1 & 2 & 3 & 3 & 9 & \\
\hline 3) & $\begin{array}{l}\text { Danger } \\
\text { according } \\
\text { to vibration }\end{array}$ & 2 & 3 & 3 & 1 & 9 & \\
\hline 4) & $\begin{array}{l}\text { Danger } \\
\text { according } \\
\text { to explosion }\end{array}$ & 4 & 5 & 4 & 3 & 16 & \\
\hline 5) & $\begin{array}{l}\text { Danger } \\
\text { according } \\
\text { to material }\end{array}$ & 4 & 4 & 4 & 3 & 15 & \\
\hline 6) & $\begin{array}{l}\text { Mechanical } \\
\text { Danger }\end{array}$ & 3 & 4 & 4 & 3 & 14 & \\
\hline 7) & Electric Danger & 4 & 5 & 3 & 1 & 13 & \\
\hline
\end{tabular}

\section{RESULTS}

The article provides a basic description of roadheaders GPK4 and AM50, which are used for excavating brown coal in the conditions of the Slovak Republic. The basic technical parameters of both mining roadheaders are also compared.

The GPK4 is in comparison with AM50 more powerful in terms of the mining work parameters, but it is heavier and needs more power output to be installed [25].

The final evaluation of versions in a pair comparison, or the weighting criterion can be achieved so that the order is "standardized", ie we require that the sum of all evaluations - weights is equal to 1 . Based on the selected criteria, K1-material handling, K2-vibration, K3-machine performance and K4-operator safety were assessed for safety risks, Table 3. According to the selected criteria, the roadheader GPK4 is more advantageous for mining works. In the second part of the article, the risks were assessed and protective measures were proposed according to the mixed method of the TNI ISO/TR 14121-2 standard for both roadheaders.
According to the order of risks, it is clear that it is necessary to design protective measures for hazards $1,4,5,6,7$, so that the risk of accidents at work is low and the handling of a particular machine is safe.

With this risk assessment, we confirmed the risks that arise from the analysis of the causes of accidents, where the main risks prevail: regular work performance and work risk", of which there were a total of 71 work accidents in the given year, which represents up to $38.58 \%$.

The accident analysis shows that the largest number of sources of accidents at work was again in the group: "material, loads, objects", especially rock falls and load handling up to 86 , which represents $46.74 \%$ and "work or road vehicles as sources of falls "And that -54 , which represents $29.34 \%$.

\section{CONCLUSION}

Coal supply requires expansion of existing and opening new mining capacities. This also makes it available to make space for deposit where geological and technical conditions are more complex, which also has an impact on working conditions and increases health and safety requirements. 
Where deteriorating mining geological and technical conditions occur, they have an adverse effect on the health of mining workers.

The adverse effect of the work environment on health is due to many influences. For example, high dust loads, the length of exposure of exposed workers to this load, as well as excessive vibrations, most often during drilling work and others. The impact of long-term stress in underground conditions is also significant.

From the point of view of safety when working in mines, it is necessary to continue to require employees to pay increased attention to any work activity (especially when handling materials, objects and loads). Attention still needs to be paid to securing vulnerable areas. Care must be taken to prevent rocks and underground walkways from falling as far as possible, in order to require their maintenance, uninterrupted operation and equipment in accordance with regulations. Observe the health and safety principles stated in the operating documentation and in the operating instructions for the device.

Protection against negative influences must be addressed in the initial phase of the project solution of mining operations and in solving the construction of mining machinery and equipment. It is not possible to neglect the health status of workers before entering a risky working environment, as well as the level of the entire system of health prevention, rehabilitation of working ability of mining workers. In practice, it is necessary to pay close attention to compliance with operating regulations, to permanently update the relevant documentation. These principles are the basis of work efficiency and safety in mining activities, as mining regulations have often been a response to serious mining accidents.

\section{ACKNOWLEGEMENT}

This contribution is the result of the projects VEGA No. 1/0075/20, VEGA 2/0080/19, APVV-19-0367.

\section{REFERENCES}

[1] Act. 124/2006 NR SR on safety and health at work and on amendments to certain laws, The law, 2006.

[2] L.T. Ostrom, CH.A Wilhelmsen. Risk Assessment, Tools, Techniques, and Their Applications. $2^{\text {nd }}$ edition, New Jersey: John Wiley and sons, 2019, pp. 56-75.

[3] K. Schwab. The Fourth Industrial Revolution: what it means, how to respond, Foreign. Switzerland: (WEF) in Davos, 2016.

[4] J. Hull. "The second industrial revolution and the staples frontier in Canada: rethinking knowledge and history." Sci Can, vol. 18, 1994, pp. 22-37.

[5] A. Toffler. The third wave. New York, Bantam books, 1980.

[6] J. Bloem, M.V. Doorn, S. Duivestein, D. Excoffier, R. Maas, V.A. Ommeren. The fourth industrial revolution: things to tighten the link between IT and OT contents. Groningen Sogeti VINT, 2014.

[7] H. Ahn, M.H. Lee. "Fourth industrial revolution impact: how it changes jobs." Korean Acad Soc Bus Adm Integr Conf, vol. 8, 2016, pp. 2344-2363.
[8] G. Graetz, G. Michaels. Robots at Work. "The Review of Economics and Statistics." MIT Press, vol. 100, 2018, pp. 753-768.

[9] De Backer T. De Stefano T. Me non C. Suh J.R. Industrial robotics and the global organisation of production $O E C D$ Science. Technology and Industry Working Papers, 2018.

[10] F. Carbonero, E. Ernst, E. Weber. Robots worldwide: the impact of automation on employment and trade. ILO Res Dep Work Pap, vol. 36, 2018.

[11] M. Sidorova, K.M. Beysembayev, M.N. Shmanov, K.M. Kanat and M.E. Aizat. "Plastic Flow Modeling in Rock Fractur", Acta Montanistica Slovaca, vol. 23, pp. 357-367. 2018.

[12] P. Hąbek, W. Biały, G. Livenskaya. Stakeholder engagement in corporate social responsibility reporting. The case of mining companies. Acta Montanistica Slovaca. ISSN 1335-1788. Volume 24 (2019), number 1, pp. 25-34.

[13] M. Taušová, J. Rybárová, S. Khouri. "Financial analysis, as a marketing tool in the process of raising awareness on renewable energy". Acta Montanistica Slovaca, vol. 12, 2007, pp. 258-263.

[14] A. Seňová, M. Antošová. "Business Performance Assessment and the EFQM Excellence Model 2010 (Case study)". Management: Journal of Contemporary Management Issues, vol. 20, pp. 183-190.

[15] W. Biały. Application of quality management tools for evaluating the failure frequency of cutter-loader and plough mining systems. Archives of Minning Sciences, Volume 62, issue 2, 2017. pp. 243-252. ISSN 0860-7001. doi 10.1515/amsc-2017-0018

[16] Technical data of the roadheader GPK4, 2018.

[17] https://dspace.vsb.cz/bitstream/handle

[18] OKD a. s., Důl Lazy. Instructions for operation and maintenance of the AM50 roadheader, Orlová: OKD a. s., Důl Lazy, 1999.

[19] Technical data of the roadheader AM50, 2018.

[20] M. Oravec, M. Balážiková, M. Tomašková. "Influence of the working environment on safety and health protection at work and of the employees in an office space". Science Business Society, vol. 3, pp. 115-121, 2018.

[21] H. Pačaiová, Š. Markulik, R. Turisová, A. Nagyová. "How to Build Risk-based Thinking Methodology Based on Process Approach". Faculty of Mechanical Engineering, the Technical University in Košice, vol. 22, 2018.

[22] J. Sinay, H. Pačaiová. "Integration model of safety and security as a part of integrated safety". Future Security, Freiburg: Fraunhofer, 2016.

[23] J. Sinay. Training, Consulting and Certification Center for risk management in machine safety, occupational health and safety and environmental risks. Potential and services of USP Technicom for efficient development of entrepreneurship and research collaboration with industry, Elfa Košice, 2015.

[24] M. Tomašková. "Risk assessment and their quantification". Safety at work, vol. 3, 2013.

[25] Group Authors. EEA, European Environment Agency. "Renewable Energy in Europe 2017. Recent Growth and Knock - on Effects EEA Report No 3/2017". Publications Office of the European Union, Luxembourg, 2017.

[26] TNI ISO/TR 14121-2. Safety of machinery. Risk assessment. Part 2: Practical guidance and examples of methods, 2009. 
[27] W. Biały. New devices used in determining and assessing mechanical characteristics of coal. $13^{\text {th }}$ SGEM GeoConference on Science and Technologies In Geology, Exploration and Mining, SGEM2013 Conference Proceedings, June 1622, 2013, Vol. 1, BULGARIA ISBN 978-954-91818-7-6/ISSN 1314-2704. pp. 547-554.

\section{Erika Škvareková}

ORCID ID: 0000-0003-2314-5686

Technical University of Košice

Faculty of Mining, Ecology

Process Control and Geotechnologies

Institute of Earth Resources

Letná 9, 04000 Košice, Slovak Republic

e-mail: erika.skvarekova@tuke.sk

\section{Marianna Tomašková}

ORCID ID: 0000-0001-6281-1501

Technical University of Košice

Faculty of Mechanical Engineering

Department of Safety and Quality Production

Letná 9, 04000 Košice, Slovak Republic

e-mail: marianna.tomaskova@tuke.sk

\section{Štefan Zelenák}

ORCID ID: 0000-0002-2872-2473

Hornonitrianske Bane Prievidza, a.s.

Matice slovenskej 10, 97101 Prievidza, Slovak Republic

e-mail: szelenak@hbp

\section{Dušan Sabadka}

ORCID ID: 0000-0001-5183-6690

Technical University of Košice

Faculty of Mechanical Engineering

Department of Automotive Production

Mäsiarska 74, 04001 Košice, Slovak Republic

e-mail: dusan.sabadka@tuke.sk

\section{Marian Šofranko}

ORCID ID: 0000-0002-1626-0144

Technical University of Košice

Faculty of Mining, Ecology

Process Control and Geotechnologies

Institute of Earth Resources

Letná 9, 04000 Košice, Slovak Republic

e-mail: marian.sofranko@tuke.sk
[28] W. Biały. Coal cutting force measurment systems (CCFM). 14 $4^{\text {th }}$ SGEM GeoConference on Science and Technologies In Geology, Exploration and Mining, SGEM2014 Conference Proceedings, June 17-26, 2014, Vol. III, BULGARIA ISBN 978-619-7105-09-4/ISSN 1314-2704. pp. 9198. 